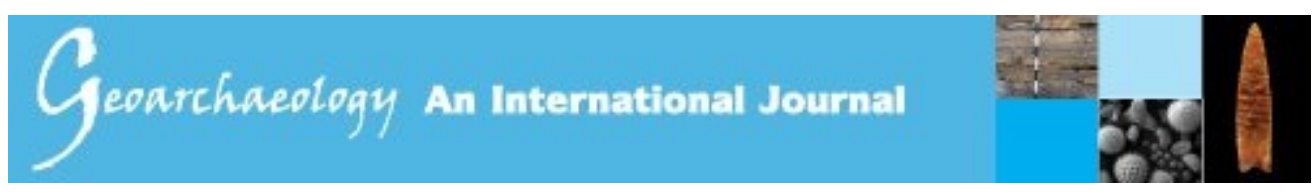

\title{
New environmental and spatial approach to Tiwanaku World Heritage site (Bolivia) using remote sensing (UAV and satellite images)
}

\begin{tabular}{|c|c|}
\hline Journal: & Geoarchaeology \\
\hline Manuscript ID & GEO-18-110.R1 \\
\hline Wiley - Manuscript type: & Review Article \\
\hline $\begin{array}{r}\text { Date Submitted by the } \\
\text { Author: }\end{array}$ & 02-Apr-2019 \\
\hline Complete List of Authors: & $\begin{array}{l}\text { PEREZ GONZALEZ, MARIA EUGENIA; Universidad Complutense de } \\
\text { Madrid Facultad de Geografia e Historia, Geography } \\
\text { Gallego, José ; UNESCO Paris, Office in Quito and representation for } \\
\text { Bolivia, Colombia, Ecuador and Venezuela }\end{array}$ \\
\hline Keywords: & Tiwanaku (Bolivia), pre-Hispanic society, UAV, DTM, satellite images \\
\hline Abstract: & $\begin{array}{l}\text { This paper analyses the research carried out in the Tiwanaku World } \\
\text { Heritage site in Bolivia, using Unmanned Aerial Vehicles (UAV) and } \\
\text { satellite images. The combined use of images with different scales has } \\
\text { made it possible to locate many archaeological structures unknown to } \\
\text { date (drainage systems, walls, circular crop marks and a possible dock). } \\
\text { The Sentinel-2 images, which were processed using principal } \\
\text { components analysis and histogram equalization, show the river beds, } \\
\text { flood-prone areas and several buried drainage channels surrounding the } \\
\text { most important structures. } \\
\text { The archaeological evidence obtained with the DTM and natural colour / } \\
\text { multispectral images enables us to contrast a new dimension of land and } \\
\text { water uses that goes beyond what was known to date. In the same way, } \\
\text { these images enable us to understand in detail the environmental } \\
\text { characteristics, land use, building distribution and flood defence } \\
\text { structures of the Tiwanaku culture throughout its history, within the } \\
\text { context of the environmental conditions of the Bolivian altiplano. } \\
\text { This investigation allowed collection of new information and posed } \\
\text { questions on the relationship of this site with water, as well as a better } \\
\text { understanding of the extent and habitat features of this historical } \\
\text { population. }\end{array}$ \\
\hline
\end{tabular}


New environmental and spatial approach to Tiwanaku World Heritage

María Eugenia Pérez González ${ }^{*}$, José Ignacio Gallego Revilla²

4

${ }^{1 *}$ Corresponding Author : Department of Geography, University Complutense of

5 Madrid, C/ Profesor Aranguren s/n, 28040 Madrid; meperez@ucm.es

6 International Consultant UNESCO. Office in Quito and representation for Bolivia,

7 Colombia, Ecuador and Venezuela.nachogare@hotmail.com

9 Abstract

10 This paper analyses the research carried out in the Tiwanaku World Heritage site in

11 Bolivia, using Unmanned Aerial Vehicles (UAV) and satellite images. The combined

\section{use of images with different scaleshasmade it possible to locate many archaeological} structures unknown to date(drainage systems, walls, circular crop marks and a possible dock). The Sentinel-2 images, which were processed using principal components analysis and histogram equalization, show the river beds, flood-prone areas and several buried drainage channels surrounding the most important structures.

The archaeological evidence obtained with the DTM and natural colour/multispectral images enables us to contrast a new dimension of landand water uses that goes beyond what was known to date. In the same way, these images enable us to understand in detail the environmental characteristics, land use, building distribution and flood defence structures of the Tiwanaku culture throughout its history, within the context of the environmental conditions of the Bolivian altiplano.

This investigation allowed collection of new information and posed questions on the relationship of this site with water, as well as a better understanding of the extent and habitat features of this historical population. 


\section{New environmental and spatial approach to Tiwanaku World Heritage site (Bolivia) using remote sensing (UAV and satellite images)}

\section{INTRODUCTION}

Tiwanaku archaeological complex (Bolivia), designated World Heritage site in 2000 by the United Nations Educational, Scientific and Cultural Organization (UNESCO), is a reference for South American archaeological science. (Bandelier, 1892; Otero, 1943; Posnansky, 1945; Browman, 1978; Kolata, 1993; Gallego \& Pérez, 2018). For over a century, research has been carried out on this site and various international teams have approached its study from multi- disciplinary perspectives, still incomplete to date. Some basic facts such as dates, social structures or physical extension, are debatedby many scientists (Couture and Sampeck, 2003; Janusek, 2003; Scarborough, 2008; Vranich, 2009, Masini et at, 2017), in relation to a site where the environmental issue is important. Nevertheless, and besides the efforts to understand the complex structure of such an important culture as that of the Tiwanaku empire, it seems that we are about to discover of a really surprising society (Ponce Sanginés, 1976), in terms of basic facts of the reality of life, in an environment as demanding as the Bolivian Altiplano; a society which spread its roots acrosswide territories over 1000 years. In different periods of its existence, Tiwanaku appeared as the centre of a huge regional empire, representing one of the most ancient state structures of South America (Browman, 1980; Ponce Sanginés, 1999; Kolata, 1993; Janusek, 2004; Goldstein, 2005). The archaeological discoveries, especially structures such as the Akapana or Puma Punku platform mounds (Protzen \& Nier, 2000: 359), the Kalasasaya temple, which conserves an outstanding monolith known as the Gate of the Sun, can be viewedin situ in anextensive environment beside 
Lake Titicaca (Ponce Sanginés, 1995). Indeed, the many archaeological remains being unearthed will certainly complement the currently available information on the life and culture of Tiwanaku, and also on its environmental relationships.

Traditionally, archaeological identification and mapping of buried structures was supported by photointerpretation, with oblique images and orthophotography (Crawford, 1929;Wilson, 1982), and more recently also by satellite imaging (Altaweel, 2005; Wiserman and El-Baz, 2007). During the long hot summer of 2018 in Great Britain, archaeologists spottedevidence of ancient sites that became visible due to the extreme dryness of the soil, (Pes, 2018).

For several years, satellite images and digital terrain models made it easy to determine some environmental characteristics of archaeological sites, such as the spatial-temporal variability of land use or resource management.Multispectral information from satellite imageswas in this way a main complement for detecting buried negative structures(drainage channels andcircular crop marks), invisible in situ because of the flatness of the terrain and its different land uses.With the passage of time and the development of on-board systems, there have been many examples of such use of aerial, satellite information and Digital Terrain Models (DTMs)worldwide: De Laet et al. (2007) used the Ikonos system to identify archaeological structures in Turkey; Lasaponara and Masini $(2007,2014)$ used Aster and QuickBird images in Tiwanaku to locate several structures, including buried channels; Trier et al. (2009) detected circular structures in Norway from high- resolution satellite images; Menze and Ur have mapped patterns of settlements in Northern Mesopotamia, (2011); Figorito and Tarantino are conducting research in Italy for the detection and extraction of archaeological traces from high resolution aerial images (2014), and Lasaponara et al. (2016) explored the use of remote sensing in Hierapolis, Turkey. However, even the 
highly accurate QuickBird images, cannot properly detect minor yet essential structures, such as domestic buildings, that can be traced by Unmanned Aerial Vehicle (UAV) generated models.

Satellite imageshaving almost global coverage, can be complemented with ultrahigh-resolution images, which are obtained byUAVs. These ultra-high resolution images have increased the options for obtaining information based on multidisciplinary approaches, particularly environmental information including basic resource catchment systems, diachronic processes, social orientation of territorial uses, anthropization and human impact on the environment, (Nikolakopoulos et al., 2016).

The wide-ranging stock of satellite images available to research teams, with different spatial resolutions and spectral resources, allows the evaluation of land use and adaptation formulas or environmental risk situations that may have been fundamental for human survival throughout history, and still are nowadays for populations in vast regions of our planet. This multidisciplinary approach is basic to understand ancient cultures.

The main aim of this paper is to advance this observation process, establishing bases for an understanding of settlement and land use in a very complex place such as historic Tiwanaku, using remote sensing, with UAV imaging supported by satellitebased data. A secondary aim is to contrast the micro scale offered by highly detailed UAV imaging and the macro scale offered by Landsat and Sentinel satellites, which complete the information provided by other authors from images of the Aster and QuickBird systems (Lasaponara and Masini, 2014).It was considered appropriate to complement information the topographic, hydrographic, geomorphologic and biogeographic characteristics of the environment of historic Tiwanaku, where so many facets remain unexplored. 


\section{STUDY AREA}

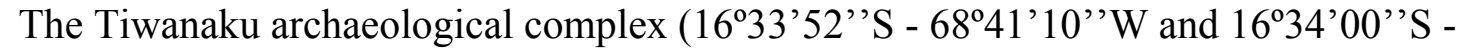
$68^{\circ} 39^{\prime} 51^{\prime}$ 'W) is located in the western La Paz department, Bolivia, $57 \mathrm{~km}$ from La Paz and $15 \mathrm{~km}$ from Lake Titicaca. Geomorphologically it is on the Central Altiplano (Andean plateau), in the Tiwanaku river basin, at $3860 \mathrm{~m}$ asl. This fluvial basin is situated between two interior plateau reliefs: to the $\mathrm{N}$ it is bounded by sedimentary hills, $320 \mathrm{~m}$ higher than the basin, reaching $4165 \mathrm{~m}$ asl; and to the S by Sierra Machaca, a great mountain chain that rises $1000 \mathrm{~m}$ above the plain to $4825 \mathrm{~m}$. asl. This difference in height between these two interior sierras creates a dissymmetric hydrographic basin, wider on the left margin, and with a minimum development on the right margin (Fig.1). The typical apparent flatness of the plateau, created by relief infill originating in the debris of a tectonic pit from the inner Andes, in this area presents some interesting relief structures, caused by different geological situations (sedimentary, alluvial, structural, etc.) characteristic of terrain where there has been very intense tectonic and volcanic activity. In fact, both sierras are still active nowadays, but their activity is weaker than in the neighbouring Andean cordilleras.

The whole mid and lower basin of Tiwanaku river, from the southern shore of Lake Titicaca, to the surroundings of Tiwanaku city itself, is characterized by a reduced slope, the frequent presence of wetlands and flood plains. The archaeological site is completely surrounded by these morphological structures, created by the abrupt slope break caused by affluent from nearby mountains crossing the plateau. The historical site rises topographically over a tabular relief, from this plain and flood prone area as shown by the regional DTM, and contrasted by the most precise UAV information. This digital ultra-high spatial resolution representation can be used to define the detail topography and some new local geomorphologic characteristics, unknown to date. 
The climate in this region of Bolivia is characterized by its altitude, and the seasonal presence of the Inter-Tropical Convergence Zone (ITCZ). Mean annual temperature is $7.7^{\circ} \mathrm{C}\left(45.8^{\circ} \mathrm{F}\right)$, with wide daily oscillation. This can be observed from mean maximum values of $13^{\circ}-16^{\circ} \mathrm{C}\left(55.4^{\circ}-60.8^{\circ} \mathrm{F}\right)$, and mean minimum temperatures below $0{ }^{\circ} \mathrm{C}\left(32^{\circ} \mathrm{F}\right)$ from May to August. The mean annual rainfall (529 $\mathrm{mm}$ ) is distributed with an evident seasonal contrast: high humidity during the austral summer (69.1\% of annual precipitation between December and March), and very dry winters, (less than 10\% between May and September).Rainfall statistics also show high interannual irregularity, with $15 \%$ of arid years $(<350 \mathrm{~mm} / \mathrm{yr})$ and $12 \%$ of wet years $(>$ $750 \mathrm{~mm} / \mathrm{yr}$ ). These interannual rainfall variations cause frequent flooding and drought, the most common natural disasters in the area, with severe social and economic implications for this Bolivian region (Latrubesse et al., 2009). Flooding frequently occurs during the summer months, causing severe variations in wetlands of the lower Tiwanaku river basin. In addition, the potential evaporation, (1431.5 mm/yr.), far exceeds annual rainfall, which certainly increases aridity.

Soil composition in the Tiwanaku area shows the influence and limitations of the altitude and extreme climatic conditions, specific to the altiplano, requiring special agricultural techniques to increase production. These techniques are basically designed to prevent periodic flooding episodes and use of surrounding water for irrigation.

Population of the site, from its uncertain beginnings up to its disappearance around $1200 \mathrm{AC}$, subsisted using these agricultural techniques with extremely interesting infrastructures, especially evident in human adaptation to the possibilities of the terrain, with raised fields (sukakollus), or lake fishing, and camelid rearing, supported by important commerce of goods including copper, wool and pottery (Kolata \& Ortloff, 1989; Kolata, 1991; Lucena, 2005; Knudson et al., 2012).Nowadays, 
151 economic activity is still based on the primary sector, with Andean crops such as potato,

152

153 oca, quinua, barley, beans, and bovine, ovine and camelid farming.

Therefore,environmental dependence, flood and drought prevention still plays a basic role in the life of the local communities.

\section{MATERIAL AND METHODS}

In this work, images of different detail and scale are combined, from very accurate, obtained from UAV, to regional ones, obtained from environmental satellites (Landsat and Sentinel). The recent use of UAV platforms in archaeological applications is explained in detail by Fernández-Hernández et al. (2015) and Forte and Campana (2016) compiling the different remote sensing techniques in archaeology.

\subsection{Raster images obtained using drones (UAV)}

In this paper two raster images were obtained, with a spatial resolution of $3.78 \mathrm{~cm} / \mathrm{pixel}$. The first was displayed in natural colour (RGB), generating a DTM with precision $4 \mathrm{~cm}$ $(\mathrm{X} / \mathrm{Y})$ and $8 \mathrm{~cm}(\mathrm{Z})$. Flight operatives were developed by Corimex Ltd., Bolivia, requested by UNESCO office in Quito, during October 2016, using a fixed wing UAV Sensefly Ebee ${ }^{\circledR}$, equipped with Canon ${ }^{\circledR}$ G9X optic (20 megapixels). The second image, using the same flight structures and operatives, was produced by Sequoya ${ }^{\circledR}$ Noptic (by Sensefly ${ }^{\circledR}$ ), in multispectral colour (G-R-nR-NIR), with spatial resolution 8 $\mathrm{cm} /$ pixel.

Records covered a total useful surface of 411.362 hectares, with three different flights at cruising altitude 137-140 m above take-off point. The flight plan(411 hectares) covered all the area included in the UNESCO 2000 declaration designating it as a World Heritage site. Final imaging was produced from calibration and mosaic 
composition of 911 individual orthophotos. All images were georeferenced to UTM zone 19S, datum WGS 84 .

\subsection{Satellite RasterImages}

Several satellite images were selected, from different dates and seasons, corresponding to scene $001 / 71$ (path/row), to analyse the geographical characteristics of the archaeological site location. Satellite type, sensor, date, spatial resolution and spectral resolution of the images used are shown in Table 1 below.

DTM was obtained from Space Shuttle Endeavour in the Shuttle Radar Topography Mission (SRTM), with a capture resolution of 3 arc second updated from Global Land Cover Facility. Landsat and Sentinel images were updated from US Geological Survey (2016a and $b)$.

The satellite information was analysed using different visual and digital filters, to improve the environmental characteristics of the area. New details ofenvironmental informationof archaeological site of Tiwanaku were obtained from natural and false color satellite images, spatial improvements (convolution, statistic and texture filters), radiometric improvements (histogram equalization, bright and fog reduction) and spectral improvements (principal components and tasseled cap).These different techniques to highlight information from satellite images are explained in detail in Chuvieco and Huete, (2009).

\section{RESULTS}

The multispectral info and temporal analysis of the Landsat and Sentinel images show all the watercourses (TiwanakuRiver and its tributary network) and a number of floodprone areas around the archaeological site (Fig. 2). As will be shown, such areas were typically characteristic in plateau regions and a critical factor for the purpose of 
establishing the physical delimitation of the archaeological site. There is a significant concentration of water in terms of annual rainfall, while the flatness of the terrain and the sparse vegetation hardly reduce surface erosion. As a result, the rivers which flow through the Machaca Mountains to the plains leave many alluvial and colluvial deposits, covering a large part of the altiplano. At the edges of these deposits there are accumulations of impermeable and thinner materials, basic for fertile soils and wetlands, visible in winter images through the extension of hydrophilic vegetation and location of cultivated land. The location of these floodplains around Tiwanaku is clearly shown by the green and light blue shades on the Landsat 5 image, which has undergone histogram equalization (top right image, Fig. 2). The archaeological site at Tiwanaku (although, curiously, the name in Aymara means "dry riverside") is specifically surrounded by flooded land, connected to what appears to be a drainage system, now abandoned, that covers all the occupied area and nearby territory. Drainage mechanisms for rainfall runoff and anthropic control of flood-prone areas around the ancient city were as necessary in the past as they are nowadays in modern Tiwanaku.As shown in Fig.2 (down-right image), the Sentinel image structured in principal components and with a convolution summary filter $3 * 3$ shows the principal riverbeds in marine blue. However, the relevant information is observed in another principal components image, which shows several drainage structures surrounding most important structures, rectangular and connected with drainage channels running NE and SW to nearby rivers (Fig. 3).This figure highlights the contrast between what is observed in a visible image (similar to a vertical photograph), and in another with infrared channels to which the principal components have been applied.

In addition to satellite imaging info, UAV images and DTM of the Tiwanaku site show us a wide range of natural forms in very high detail. In order to understand 
this applied resource, a brief analysis of both natural and anthropic features is advanced below:

\subsection{Natural elements analysed by UAV images}

The different geomorphological units which, many cases have been used or remodelled by man are:

\subsubsection{Altiplano surface in Tiwanaku}

At 3845-3857 m asl, with irregular micro-topography, slightly banked to the $\mathrm{N}$ and with small natural depressions and drainage channels. This surface is situated $10-20 \mathrm{~m}$ above the flood plains and wetlands surrounding the Tiwanaku archaeological site (Fig. 4).

\subsubsection{Dolines and fractures}

Dolines are natural rounded or elliptic depressions,caused by dissolution processes and the collapse of the surface terrain. They are 70-100 m long and 30-40m wide, flat bottomed, soil lined and 1-2 m deep (Fig. 5). Evidence of the presence of underlaidlimestone could explain the tabular relief of the topographic location of Tiwanaku, with higher erosion resistance capabilities compared with the rest of the surrounding detrital materials. Both the ancient and modern cities of Tiwanaku are located in this position, slightly above the plateau. These dolines tend to be seasonally flooded, especially in December and January, months with maximum summer rainfall. These natural water storage features are currently often used for cattle rearing and agriculture, and judging by the archaeological remains distributed around them, were also used for these purposes in the past.Most of the dolines are aligned, with a predominant NE - SW and EW and NW - SE orientation, which indicates the presence of a fractured substrate, and thus favours the dissolution and collapse of the land 
246 surface, and its subsequent seasonal flooding (Fig. 5, at the top right).

\section{$247 \quad$ 4.1.3Flood plains}

248 These are distributed throughout the surroundings of Tiwanaku archaeological site and

249 are related to the Tiwanaku River and its left bank tributaries. North of the Akapana

250 platforms mound, the river flood plain is found at $3832-3833 \mathrm{~m}$ asl, just $1-2$ meters

251 above the present river course, with a maximum transversal axis of 348-393 $\mathrm{m}$. Current

252 land use of some of these terrains has been recently use for testing traditional techniques

253 of raised fields(sukakollus) with the aim of reducing plant exposure to soil freezing and

254 flooding in these severe climatic scenarios (Fig. 6 at the right). On the western bank of

255 the Puma Punku zone, the flood plain is situated at $3833-3837 \mathrm{~m}$ asl and is mostly

256 uncultivated because of ground water saturation during the greater part of the year, (Fig.

$257 \quad 6$ at the left).

$258 \quad 4.2 \mathrm{UAV}$ analysis of buried anthropic elements

259 Generally speaking, there are two common types of structures in archaeology, known as

260 positive and negative, according to their appearance and location in a stratigraphic

261 context (Crawford, 1929; Wandsnider, 1996). A typical positive structure might be a

262 wall, whereas a typical negative structure could be, for instance, a moat. Depending on

263 the possible anthropic use of these new archaeological locations, the following

264 differential issues can be considered:

\section{$265 \quad$ 4.2.1 General distribution of thesettlement pattern}

266 According to all the above information on the site location and neighbourhood and the

267 surrounding flooded areas, the potential houses occupation can be clearly affirmed at

268 the maximum point of expansion (Fig. 7). Starting from this information, during the

269 culminating period of Tiwanaku society and culture, there was a complex settling plan 
and structure, with a socially determined space, structured by a large square drainage moat,located in an evidently principal $\mathrm{N}$ position. From this preeminent centralnorthern position, the city population expanded to $\mathrm{S}, \mathrm{E}$, and $\mathrm{W}$. The monumental structure still found nowadays outside this evidently sacred space is the Puma Punku complex, detailed below.

\subsubsection{Evidence of buried buildings}

A wide variety of constructions, differentiated according to their potential use, can be found throughout the study area. First of all, this shows that the occupied area at the moment of maximum expansion of the Tiwanaku site exceeds the zone studied using UAV zone (411 hectares). In fact, satellite information has been basic for this task area and it is this resource which has shown the real extension of the central nucleus of the ancient city, slightly over 650 hectares, (Fig.7). Additionally, some regular features can be observed in the surrounding areas, presenting obviously anthropic patterns. This side evidence refers to radial locations of archaeological interest, outside the main city concentration. However, the square moat observed by Lasaponara and Masini (2014), Vranich and Levine(2013)or Ortloff, and Janusek (2016) and its exact location within the Tiwanaku settlement plan itself is now confirmed. Its position is clearly marked in the central - north position into city structure, and contained inside it are the main religious and political spaces of the city, such as the Akapana platforms mound, Kalasasaya temple, Putuni complex, etc. Its southern trace has been clearly destroyed by modern train track, although its eastern and western vertices are still perfectly marked and are visible in the DTM, as well as the directionality of its turn. There is also interesting new information about this restrictedarea,with the existence of radial raised platforms, attached parallel to the moat, that increase the inner height of thesenew structures(Fig. 8).This is a 3D image using Global Mapper from the NW corner of the 
pit. It shows the presence of the remains of these structures. Ancient rescue excavations in the area indicated a massive accumulation of clay. They give us direct information that is difficult to reflect in the text, but that provides conclusive data about what the

DTM shows.Although we cannot affirm that the purpose of them was defensive, it is logical to consider that they establish a formal delimitation of the inner area and its buildings, in contrast to what lay outside. Complex structural volumes can also be seen in the western Akapana area, as well as what seems to be a massive square structure, unknown to date, just to the south of the Putuni complex (Fig. 7a), and sharing many similarities with the so called sarcophagus palace, as recently revealed by the test excavations (Gallego \& Pérez, 2018).

With reference to the distribution in terms of areas covered, a widespread dispersion of orthogonal volumes (rectilinear and perpendicular) can be observed across the whole area of the site, inside and outside the drainage moat.In this regard, the linear and perpendicular shapes denote anthropic elements (Fig.7a, 7c, and Fig. 9, 1 to 5). As we have comparative information from previous archaeological works in Tiwanaku, we are able to identify some of them as areas of domestic occupation, in view of their common constructive patterns (Janusek, 2003). On the other hand, the multispectral register shows the existence of negative structures, in this case, traces of broad groupings of potential circular cabins, established in several scattered nuclei in the area, particularly beside wetlands (Fig.10).

With reference to the massive structures located outside the moat, a brief comment on Puma Punku is appropriate here. At present, analysis of the UAV images shows that this structure is much more complex than previously thought. The drone images clearly show the existence of, at least, two overlapping square platforms, and also asquare plaza (Fig. 7c). The structural regularity is evidence of the durable 
construction materials used. The E-W orientation of the whole complex is clearly evident, leading straight to the nearby wetlands. In addition, on the south side of the complex, there is massive evidence of large stone-built structures with possible relation with the Inka reoccupation and transformation of the monument, and two nuclei with circular traces (Fig. 10). These are also very interesting, as they can stablish a sequence of occupation of this area, out of the classic Tiwanaku period.

\subsubsection{Drainage channels and ditches}

Natural colour image obtained by UAV clearly shows evidence of various drainage systems in Tiwanaku, complementing information provided by Lasaponara and Masini (2014). The drainage infrastructure is linked to the Tiwanaku River and related wetlands, and is composed of a large square moat and several drainage channels. Some of these are orthogonal and others just use natural structures (Fig. 7, and 7c), draining to the neighbouring floodplains.As for the presence of dikes (Fig. 7b), both the information obtained from testing and the archaeological work done during 2017 have confirmed the use of large clay platforms to establish the perimeter of the occupation area. Possibly the result of massive public works and having a very different use based on the space it occupies, in relation to the floodplain.

\section{DISCUSSION}

Multi-spectral imagery can also enhance the identification of otherwise invisible archaeological sites, particularly in the near-infrared part of the spectrum (Aqdusa et al., 2012). The combined use of satellite and UAV images in the archaeological site of Tiwanaku allows substantially improving the cartography of numerous buried structures and confirming others previously detected, with other satellite images (Lasaponara \& Masini, 2014) or through other archaeological techniques (Cothren et al., 2008; Kolata \& Ortlof, 1989; Kolata, 2003). In addition, the 
345 analysis of the regional and local territory (altitude, landforms, hydrology and

346 land use) provides some indication of the relationship between the Tiwanaku

347 community and the environment, in which the defence and use of water were vital

348 in the Andean Altiplano.

349 Although topographic aspects of Tiwanaku had been previously

350 investigated by William et al. (2007), the comparative analysis of the physical

351 environment at different scales better determines its location on a worn and

352 fractured tabular surface, which barely rises 10-20 $\mathrm{m}$ above the base level of the

353 Altiplano. Cothren et al. (2008) used photogrammetry on conventional aerial

354 photography, together with different geophysical studies to compose a first model

355 of topological approach to the site. Years later, Lasaponara (2014) used the

356 regional MDT of the ASTER satellite to locate the Tiwanaku settlement. But in

357 both situations the altimetric accuracy of the DTM obtained from drones

358 substantially improves the identification of both the underlying archaeological

359 elements and the geographic features.This is the case of the numerous natural

360 depressions (dolines) that originate on the surface, which are also aligned to

361 favour fractures of the underlying rock and are seasonally flooded. In the past, this

362 has allowed for the temporary storage of fresh water, being a great help for

363 livestock and the local population.

In addition, the RGB and MDT images provided by the UAV system

366 floodplains surrounding Tiwanaku and the various land uses, depending on the

367 frequency of the floods. This land, exposed seasonally to heavy rains (hourly,

368 daily and monthly), requires mechanisms for the defense and use of water, being

369 as essential then as it is now. These mechanisms, such as raised field cropping 
systems, or the creation of dams that effectively control the impact of flooding inside the city, and their implementation in certain areas such as river docks for the management of critical materials for the construction of monumental buildings, are now clearly visible and identifiable from UAV information.

The use of natural colour images, plus DTM -generated images, allowed detection of many positive structures, such as fences, terraces or platforms. On the other hand, multispectral imaging allowed us to detect several negative structures, including circular evidences, foundations, plazas or drainage channels (De Laet et al. 2007; Lasaponara and Masini, 2007; Aqdusa et al. 2012; Forte and Campana, 2016).In this regard from the archaeological point of view, inspection of ultrahigh spatial resolution images of 411 hectares has allowed to determine the extension of the old nucleus, which seems to exceed this size, reaching about 650 hectares, as noted in the preliminary analysis of the results obtained from a second flyby, whose information will be presented shortly and that significantly increases the extension established by the previous findings.

Leaving aside the investigation of great monuments, whose presence often obscures other features of great interest for research related to the general structure of a site like Tiwanaku, it is noted that the extensive area it covers is structured in different zones; this has been confirmed by data obtained from various excavations and geophysical investigations. As an example, in the Mollo Kontu area (Williams et al., 2007), south of Akapana platforms mound, the distribution of occupied areas, at least during the Tiwanaku V period, was structured in neighborhoods, districts with massive linear stone and adobe fences. This structuring is confirmed in other regions like East Akapana or Chii ji Jawira (Janusek, 1999; 2004), and can also be observed in the DTM image. There is also 
395 an evident presence of divergent elements which, a priori, are indicative of other

396

occupation phases. One of the most evident is the presence of circular structures,

which in theory could be linked to the outer stages of the Tiwanaku culture

(Bandelier, 1911; Browman, 1978 and 1980; Williams et al. 2007). It is noted that western bankclay structure that we found besides Puma Punku may have been used as a possible seasonal river dock, linked to a wide flooding area and the fluvial structure of Tiwanaku River.It could have been potentially created for the unloading and initial storage of clay and red sandstone(Gallego and Perez, 2018), this one obtained from the Kaliri quarry (Janusek et al., 2012), about 15 kilometres to the south.

From our geo-archaeological perspective, there is also evidence of several hydraulic structures, designed to control local soil saturation conditions, mass loss and sediment transport as established by Ortloff and Kolata (1989), Kolata et al. (1991) and Orloff (2016); according to these authors, the Tiwanaku society engaged in an intensive agricultural production, with the creation of an artificial and regional hydrological regime of channels, aqueducts and groundwater regulation. This evidence can currently be traced at several points on the site. UAV images have confirmed these hypotheses, and the topography of the sub-aerial channel network can be mapped with centimeter-level accuracy.

In this regard, it should be noted that the land to the west of the Puma Punku complexhas a high recurrence of floods and offers scarce agricultural use. Nevertheless, flood intensity is lower in the floodplain of the Tiwanaku River, where farming systems in raised fields have been archaeologically identified (Kolata and Ortloff, 1989, Kolata et al. 1991 and Janusek \& Kolata, 2004). Today, 
419 this technique is still one of the best resources against frost, so common in the

420 Altiplano, at an altitude of more than $3840 \mathrm{~m}$ a.s.1.

421

422

423

424

426

427

\section{CONCLUSION}

The geographical and archaeological study of Tiwanaku (Bolivia) using remote sensing has given us a new perspective regarding the location of this site in two essential areas: the analysis of the territory and the distribution of ancient urban spaces.

Images obtained with spectral improvement to the principal components and radiometric improvement of histogram equalization have made it possible to create high resolution maps of all of the bodies of water and determine the overallshape of the structures and formations that made up the water network.

Methodologically, the combination of images at different scales has been fundamental: medium (satellite and MDT), and small (obtained from a drone). Their joint interpretation has permitted several discoveries to be made regarding the archaeological site of Tiwanaku:

- The site is located on a nearly horizontal geological structure, which is highly worn but slightly elevated above the base level of the plateau. In addition, this residual relief is extremely fractured and has many forms caused by dissolution and collapse.

These areas are seasonally flooded, so they are a good reserve of fresh water.

- It is surrounded by flood plains formed to the north with the sediment transported by the river of the same name (Tiwanaku), and to the east, south and west by the streams that descend from the Sierra de Machaca to the high plateau. In these floodplains, which are the most fertile, traditional farming practices were performed inraised fields to minimize frost damage, a technique that presumably was inherited from the ancient Tiwanaku.These practices have today been mainly lost. 
- All of the floodplains closer to Tiwanaku, such as those found between Lake

444 Titicaca and the archaeological site, can be accurately mapped thanks to the radiometric

improvements in principal components and histogram equalization of Landsat and

clearly observethe large rectangular drainage structure that encloses the main observable monuments, as well as the connections to the discharge areas.

- Other smaller buried elements have been precisely locatedusing the DTM obtained by the drone. The level of detail is $4 \mathrm{~cm}$, which is better than the visible or infrared images with the same resolution. Other smaller drainage channels, circular marks and numerous buried walls have been identified in the vicinity not only of Akapana, but also of Puma Punku and other lesser-known areas. This indicates that the built-up area of the Tiwanakuarchaeological site was much larger than previously believed, and its extension may be as large as 650 ha. This last figure is based on additional information that is provided below.

- Finally, in front of the elevated platform of Puma Punku, the very high spatial resolution DTM reveals the existence of a perimeter enclosure structure. Its presence can be detected intermittently at different points along the urban boundary, along with a possible fluvial dock, which is linked to a very powerful flood plain. If these two structures were confirmed, it would be necessary to recognize that floods in this region of the altiplanowere much higher during the diffuse period between the beginning of this population (first or second millennium BP) and its disappearance around 1200 AC. In this context, the renowned Aymara words thia (riverside) and wañaku (dry), which apparently gave rise to Tiwanaku, would make sense. Even though these discoveries are remarkable, they currently do not allow anything else to be ventured, since this new line of research requires additional data and new fieldwork. 


\section{ACKNOWLEDGEMENT}

470

This paper was supported by Research group Remote Sensing and Global Change of University Complutense of Madrid, and contract N ${ }^{\circ}$ 4500313851/2016 between UNESCO Office in Quito and representation in Bolivia, Colombia, Ecuador and Venezuela, and Universidad Complutense de Madrid, as a part of the UNESCO Project of Conservation and Preservation of Tiwanaku (Bolivia) and Akapana pyramid(2015 - 2017).

\section{REFERENCES}

Altaweel, M (2005). The use of ASTER satellite imagery in archaeological contexts. Archaeological Prospection, 12, 151-166.

Aqdusa, S.A., Hansonb, W.S., Drummonda, J. (2012). The potential of hyperspectral and multi-spectral imagery to enhance archaeological cropmark detection: a comparative study. Journal of Archaeological Science, 39(7), 1915-1924.

Bandelier, A.F.A., (1892). Final Report of Investigations Among the Indians of the Southwestern United States Carried on Mainly in the Years from 1880 to 1885 , Vol. 3. University Press.

Bandelier, A.F.A. (1911). The Ruins at Tiahuanaco. American Antiquarian Society. Browman, D.L. (1978). Toward the development of the Tiahuanaco (Tiwanaku) state. In D.L. Browman (Ed.), Advances in Andean Archaeology, 327-349. Mouton, The Hague.

Browman, D.L. (1980). Tiwanaku expansion and altiplano economic patterns. Estudios Arqueológicos, 5, 107-120.

Chuvieco, E. \& Huete, A. (2009). Fundamentals of Satellite Remote Sensing. CRC Press.

Cothren, J., Goodmaster, C., Barnes, A., Ernenwein, E., Vranich, A., Fredrick Limp, W. Payne, A. (2008). Fusion of Three-Dimensional Data at Tiwanaku: An Approach to Spatial Data Integration. Proceedings of the Computer Applications and Quantitative Methods in Archaeology. 2008/4.

Couture, N.C., \& Sampeck, K. (2003). Putuni: A history of palace architecture in Tiwanaku. In A.L. Kolata (Ed.), Tiwanaku and its hinterland: Archaeology and paleoecology of an Andean civilization, Vol. 2, 226-263. Washington, DC: Smithsonian Institution Press. 
501 Crawford, OGS. (1929). Air-photography for archaeologist. Ordnance Survey Professional Papers, New Series, 12. HMSO, Southampton, UK.

De Laet, V., Paulissen, E. \& Waelkens, M. (2007). Methods for the extraction of archaeological features from very high-resolution Ikonos-2 remote sensing imagery, Hisar (southwest Turkey). Journal of Archaeological Science, 34, 5: 830-841.

Figorito, B. \& Tarantino, E. (2014). Semi-automatic detection of linear archaeological traces from orthorectified aerial images. International Journal of Applied Earth Observation and Geoinformation, 26, 458-463.

Fernández-Hernández, J.; González-Aguilera, D.; Rodríguez-Gonzálvez, P. \&ManceraTaboada, J. (2015). Image-Based Modelling from Unmanned Aerial Vehicle (UAV) Photogrammetry: An Effective, Low-Cost Tool for Archaeological Applications. Archaeometry, 57, 1, 128-145.

Forte, M. \& Campana, S.R.L. (Eds.). (2016). Digital Methods and Remote Sensing in Archaeology. Archaeology in the Age of Sensing. Springer.

Gallego-Revilla, J.I. \& Pérez-González, M.E. (2018). Tiwanaku, entre el cielo y la tierra. UNESCO. Paris.

Goldstein, P.(2005).Andean Diaspora. The Tiwanaku Colonies and the Origins of South American Empire. University Press of Florida, Gainesville.

Janusek, J. W. (1999). Craft and local power: Embedded specialization in Tiwanaku cities. Washington D.C. Latin American Antiquity, 10 (2), 107-131.

Janusek, J.W. (2003). The changing face of Tiwanaku residential life: State and social identity in an Andean city. In A.L. Kolata (Ed.), Tiwanaku and its hinterland: Archaeology and paleoecology of an Andean civilization, 2, 264-295. Washington, DC: Smithsonian Institution Press.

Janusek, J.W. (2004).Identity and Power in the Ancient Andes. Tiwanaku Cities Through Time. Routledge, New York.

Janusek, J.W. \& Kolata, A.L. (2004). Top-down or bottom-up: rural settlement and raised field agriculture in the Lake Titicaca Basin, Bolivia. Journal of Anthropological Archaeology, 23(4), 404-430.

Janusek, J. W., Williams, P.R. \& Golito, M. (2012). Building Taipikala: Teluric transformations in the Lithic Production of Tiwanaku. In N. Tripcevich y K.J. Vaughn (Editors). Mining and Quarrying in the ancient Andes: Socio-political, Economic and Symbolic Dimensions. Springer, 66-97. 
Knudson, K.J., Gardella, K.R., Yaeger, J. (2012). Provisioning Inka feasts at Tiwanaku, Bolivia: the geographic origins of camelids in the Puma Punku complex. Journal of Archaeological Science, 39(2),479-491.

Kolata, A.L (1991). The Technology and Organization of Agricultural Production in the Tiwanaku State. Latin American Antiquity, 2(2), 99-125.

Kolata, A.L. (1993). The Tiwanaku: Portrait of an Andean Civilization. Blackwell, Cambridge, MA.

Kolata, A.L. (2003). Tiwanaku and its hinterland: Archaeology and paleoecology of an Andean civilization, 2. Washington, DC: Smithsonian Institution Press.

Kolata, A.L.\& Ortloff, Ch. (1989). Thermal analysis of Tiwanaku raised field systems in the Lake Titicaca Basin of Bolivia. Journal of Archaeological Science, 16(3), $233-263$

Lasaponara, R. \& Masini, N. (2007). Detection of archaeological crop marks by using satellite QuickBird multispectral imagery. Journal of Archaeological Science, $34(2), 214-221$.

Lasaponara, R. \& Masini, N. (2014). Beyond modern landscape features: New insights in the archaeological area of Tiwanaku in Bolivia from satellite data, International Journal of Applied Earth Observation and Geoinformation, 26, 464-471.

Lasaponara, R, Leucci, G, Masini, N, Persico, R,\& Scardozzi, G. (2016). Towards an operative use of remote sensing for exploring the past using satellite data: the case study of Hierapolis (Turkey). Remote Sensing of Environment, 174, 1, 148 164.

Latrubesse, E.M., Bakerb, P.A. \& Argolloc J. (2009). Geomorphology of Natural Hazards and Human-induced Disasters in Bolivia. Developments in Earth Surface Processes, 13: 181-194.

Lucena Salmoral, M. (2005). Atlas histórico de Latinoamérica. Desde la prehistoria hasta el siglo XXI. Ed. Síntesis, 252 pp.

Marsh, E. (2016). Building Household and Community through Active Assemblages: A Late Formative Patio Group at Khonkho Wankane, Bolivia. Cambridge Archaeological Journal, 26. Cambridge University Press. 305-327.

Masini, N., Sileo M., Lasaponara, R., Leucci, G., Orefici, G., \& Rizzo, E. (2017). Archaeogeophysical investigations in Tiwanaku: preliminary results. Geophysical Research Abstracts, 19. 
Menze, BH, Ur JA (2011) Mapping patterns of long-term settlement in Northern Mesopotamia at a large scale. PNAS 109 (14), E778-E787.

Nikolakopoulos, K., Soura, K., Koukouvelas, I., \& Argyropoulos, N.G. (2016). UAV VS classical aerial photogrammetry for archaeological studies. Journal of Archaeological Science: Reports. doi:10.1016/j.jasrep.2016.09.004.

Ortloff, Ch.R. (2016).New discoveries and perspectives on water management at $300 \mathrm{bc}$ - ad 1100 Tiwanaku's urban center (Bolivia). Open Access investigation. https://www.academia.edu/30336746/NEW DISCOVERIES_AND_PERSPEC TIVES ON WATER MANAGEMENT AT 300 BCAD 1100 TIWANAKUS URBAN CENTER BOLIVIA HYDROLOGY CU RRENT RESEARCH 31 OPEN ACCESS 2016

Ortloff, Ch.R.,\& Kolata, A.L. (1989). Hydraulic analysis of Tiwanaku aqueduct structures at Lukurmata and Pajchiri, Bolivia. Journal of Archaeological Science, 16(5), 513-535.

Ortloff, Ch. \& Janusek J.W. (2016). Hydrologic Engineering of the Tiwanaku. In: Encyclopaedia of the History of Science, Technology, and Medicine in NonWestern Cultures. Springer.

Otero, G. A. (Ed.). (1943). Tihuanacu. Emecé Editores. Buenos Aires.

Pes, J. (2018). Amid Record Heat, England's Bone-Dry Soil Is Revealing the LongHidden Patterns of Ancient Buried Ruins. Artnet news. https://news.artnet.com/art-world/uk-heatwave-archaeology-find-1333235

Ponce Sanginés, C. (1976).Tiwanaku: Espacio, tiempo y cultura. Ensayo de síntesis arqueológica. Tercera edición.Ediciones Pumapunku. La Paz.

Ponce Sanginés, C. (1995). Tiwanaku: 200 años de investigaciones arqueológicas. Primera edición. Producciones Cima. La Paz.

Ponce Sanginés, C. (1999). Tiwanaku un estado precolombino: contribución a la arqueología política. Producciones Cima. La Paz.

Posnansky, A.(1945). Tihuanacu,the cradle of American man. New York, J.J. Augustin. doi: 10.1007/978-0-387-74907-5_55.

Protzen, J. P. \& Nair S. E. (2000).On reconstructing Tiwanaku architecture. Journal of the Society of Architectural Historians, Vol. 59 No. 3. 358-371. 
600 Scarborough, I. (2008). The Bennett Monolith: Archaeological Patrimony and cultural

601

602

603

604

605

606

607

608

609

610

611

612

613

614

615

616

617

618

619

620

621

622

623

624

625

626

627

628

629

630 restitution in Bolivia. In Silverman, H. \& Isbell, W.H, (Eds), Handbook of South American Archaeology, 1089-1101. Springer.

Trier, ØD., Larsen, SØ., Solberg, R. (2009). Automatic detection of circular structures in high resolution satellite images of agricultural land. Archaeological Prospection, 16,1-15.

USGS (2004), Shuttle Radar Topography Mission,1 Arc Second scene SRTM_u03 f03 $\_001$. Global Land Cover Facility, University of Maryland, College Park, Maryland, February 2000. http:/glcf.umd.edu/data/srtm/.

U.S. Geological Survey (USGS). (2016a). Landsat5TM. Acquisition Date: 10-Oct-2016 for Scene: L5001071_08021987. Earth Resources Observation and Science (EROS) Center.

U.S. Geological Survey (USGS). (2016b). Sentinel-2. Acquisition Date: 25-NOV-16 for Scenes2a_oper_msi_11c_tl_sgs_20160427t232756_a003854_t19keb. European Space Agency (ESA).

Vranich, A. (2006).The Construction and Reconstruction of Ritual Space at Tiwanaku, Bolivia (A.D. 500-1000). Journal of Field Archaeology,31(2), 121-136.

Vranich, A. (2009). The development of the ritual core of Tiwanaku. In YoungSanchez,M. (Ed.), Tiwanaku: Papers from the 2005 Mayer Center Symposium at the Denver Art Museum (pp. 11-34). Denver, CO: Denver Art Museum.

Vranich; A. \& Levine, R. (2013). Advances in Titicaca Basin archaeology-2. Los Angeles: Cotsen Institute of Archaeology Press, University of California

Wandsnider, L. (1996). Describing and comparing archaeological spatial structures. Journal of Archaeological Method and Theory, 3, 4, 319-384.

Williams, P.R., Coture, N. \& Blom, D. (2007). Urban Structure at Tiwanaku: Geophysical Investigations in the Andean Altiplano. In Wiserman, J.R. \& ElBaz, F. (Eds.), Remote Sensing in Archaeology, 17,423 - 441.

Wilson, D.R. (1982). Air Photo Interpretation for Archaeologists. St. Martin's press. London.

Wiserman, J.R., \& El - Baz, (Eds.). (2007). Remote Sensing in Archaeology. New York. Springer. 
632 Table 1. Selection of satellite images of Tiwanaku archaeological complex used in this 633 study.

634 Figure 1. Study area and detail of general DTM (exaggerationx 8). Source, USGS 635 (2004)

636 Figure 2.Top: Landsat image andhistogram equalization detail (1987); down:Sentinel 2 637 image and principal components detail(2016). Source: U.S.Geological Survey

638 Figure 3. Principal components image (4-2-3, R-G-B), Sentinel 227 April 2016, and 639 buried drainage structures

640 Figure 4. Detail of Bolivian Altiplano topography obtained from DTM. 1: from the 641 Tiwanaku River to the western floodplain; 2: from the river Tiwanaku to the south of 642 Akapana raised platform

643 Figure 5. Natural structures in Tiwanaku, Bolivia: dissolution forms and fractures in 644 MDT image anddetail of flooded dolines in Google Earth $\subset$ image (December 2003) 645 Figure 6. Left: Flood plains surrounding the Tiwanaku archaeological complex, 646 obtained by UAV, November 2016. Right: detail of raised fields system, in northern 647 Akapana territory

648 Figure 7.Detail of MDT: The archaeological site location, the neighbourhood and the 649 surrounding flooded areas. (a): positive structures near of Akapana raised platform; (b): 650 negative structures, channels and (c): positive structures near the Puma Punku raised 651 platform

652 Figure 8.3D rendering of NW corner of Tiwanaku's moat, by $16 \mathrm{~cm}$ resolution DTM.

653 Marked with red arrows, position of remains of raised platforms attached to inner 654 border of the moat.

655 Figure 9.Location in Google Earth (up) and 3D Model (down): Puma Punku complex 656 area view, obtained by DTM. Several structures can be observed linked to previously 
657 identified raised platform: 1. Western complex buildings; 2. Puma Punku raised

658 platform; 3. Eastern Platforms; 4. Southern buildings; 5. Eastern plaza

659 Figure 10. Multispectral imaging of southern Puma Punku area, with circular crop

660 marks, compared with Khonkho Wankane site's domestic information (Marsh, 2016) 


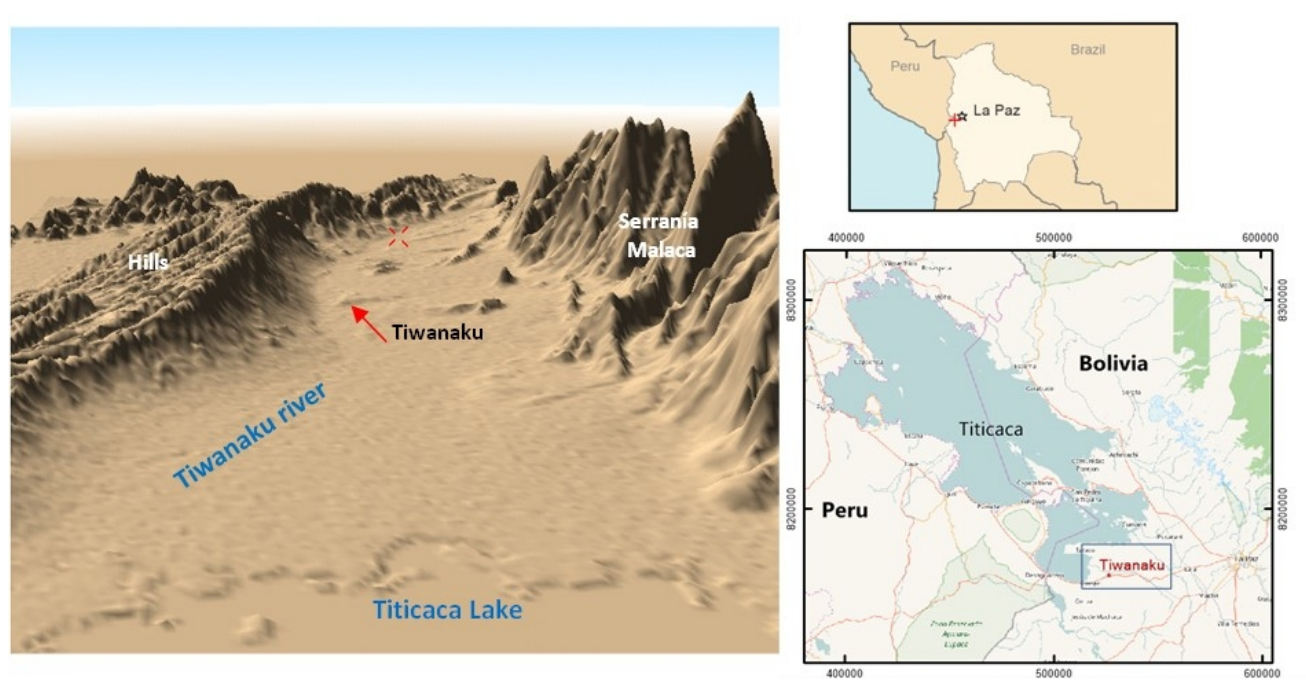

Figure 1. Study area and detail of general DTM (exaggeration x 8). Source, USGS (2004) $160 \times 81 \mathrm{~mm}(150 \times 150 \mathrm{DPI})$ 


\begin{tabular}{llll}
\hline Satellite/Sensor & $\begin{array}{l}\text { Date } \\
(\mathrm{dd} / \mathrm{mm} / \text { yyyy })\end{array}$ & $\begin{array}{l}\text { Spectral resolution } \\
(\mathrm{m} \text { per pixel })\end{array}$ & $\begin{array}{l}\text { Spectral resolution } \\
(\text { Bands })\end{array}$ \\
\hline Landsat 5 & $08 / 02 / 1987$ & $30 \mathrm{~m}$ & 6 bands (VIS, NIR, \\
& $120 \mathrm{~m}$ & $\begin{array}{c}\text { SWIR) } \\
\text { band (TIR) }\end{array}$ \\
Sentinel 2 A & $27 / 04 / 2016$ & $10 \mathrm{~m}$ & 4 bands (VIS, NIR) \\
& & $20 \mathrm{~m}$ & 6 bands (NIR, SWIR) \\
& $60 \mathrm{~m}$ & 3 bands (aerosols, water \\
$\begin{array}{l}\text { Space Shuttle Endeavor } \\
\text { C\&X bands }\end{array}$ & Feb of 2000 & $90 \mathrm{~m}$ & 1 C-band and X-band
\end{tabular}




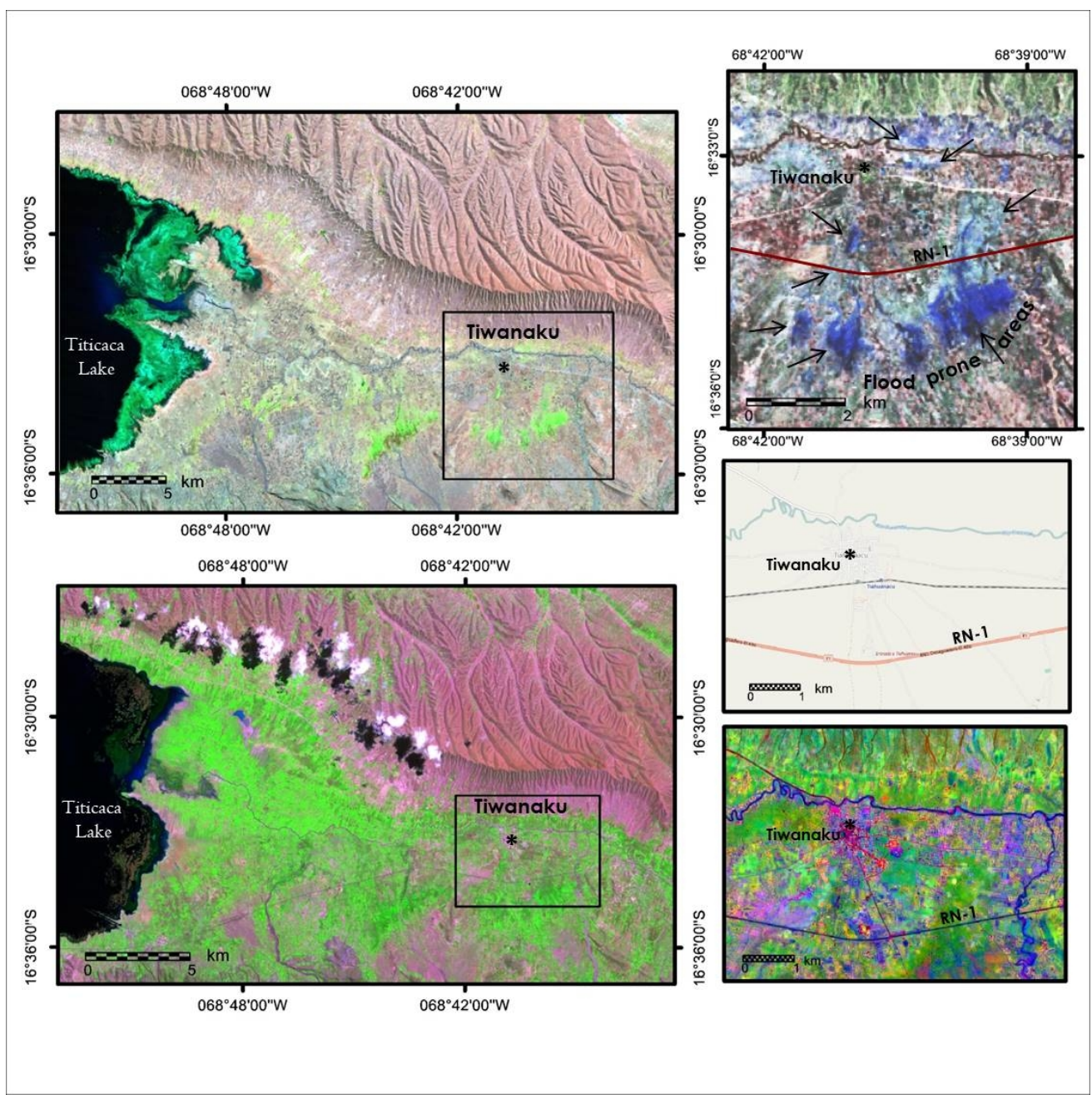

Figure 2. Top: Landsat image and histogram equalization detail (1987); down: Sentinel 2 image and principal components detail (2016). Source: U.S.Geological Survey

$190 \times 190 \mathrm{~mm}(150 \times 150 \mathrm{DPI})$ 

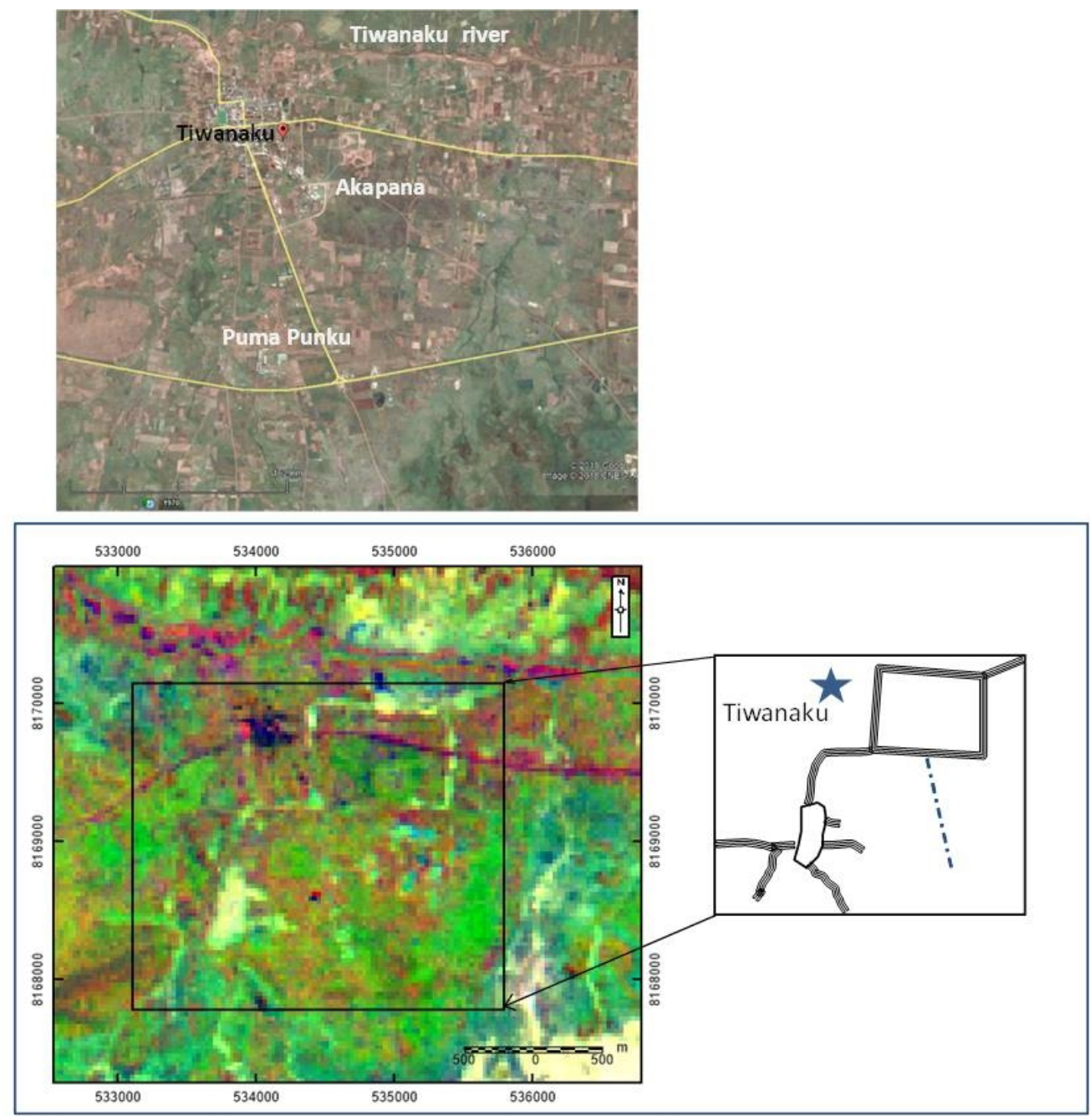

Figure 3. Principal components image (4-2-3, R-G-B), Sentinel 227 April 2016, and buried drainage structures

$140 \times 142 \mathrm{~mm}(150 \times 150 \mathrm{DPI})$ 
Figure 4. Detail of Bolivian Altiplano topography obtained from DTM. 1: from the Tiwanaku River to the western floodplain; 2: from the river Tiwanaku to the south of Akapana raised platform

$$
140 \times 71 \mathrm{~mm}(150 \times 150 \mathrm{DPI})
$$




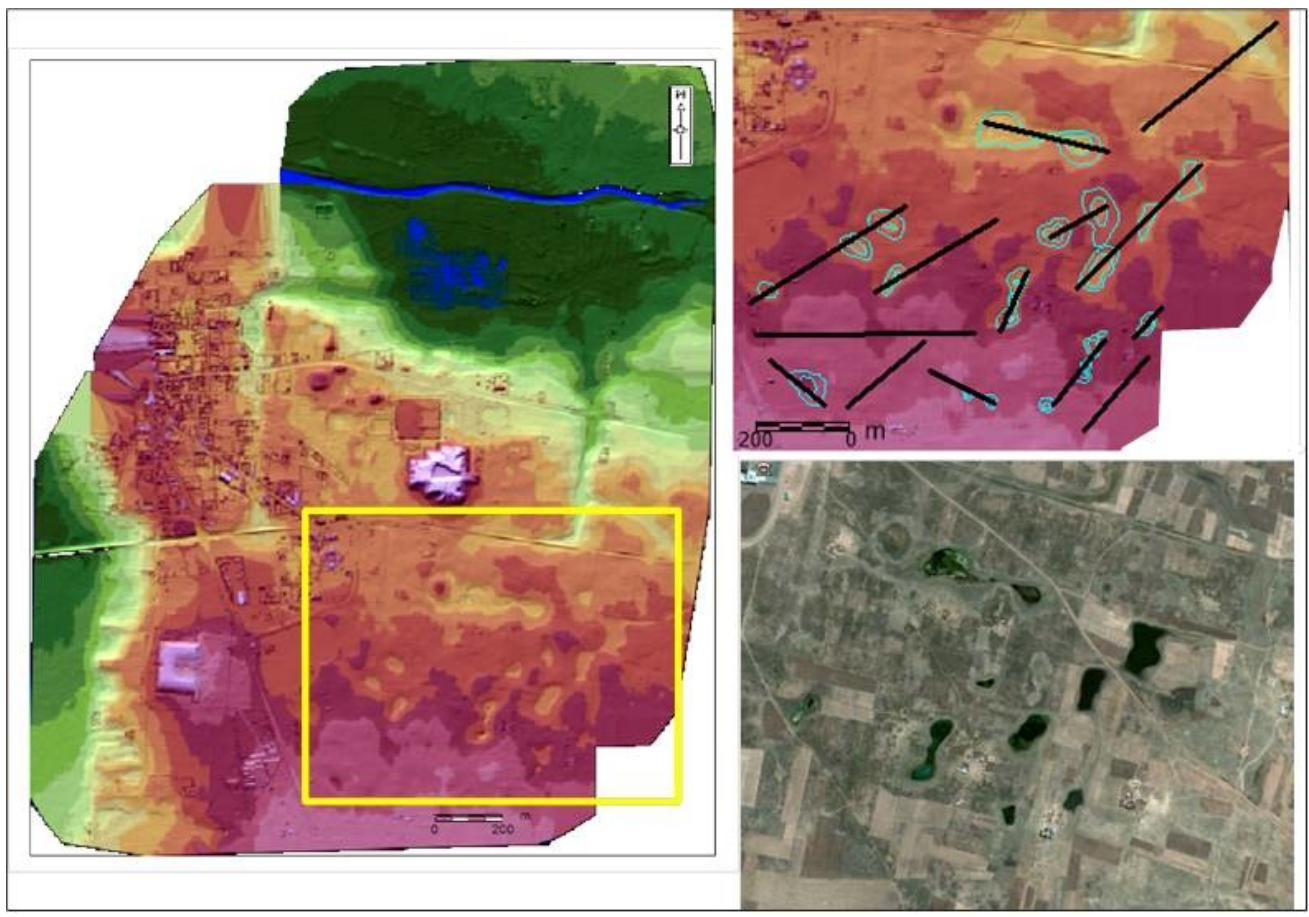

Figure 5. Natural structures in Tiwanaku, Bolivia: dissolution forms and fractures in MDT image and detail of flooded dolines in Google Earth $\subseteq$ image (December 2003)

$133 \times 92 \mathrm{~mm}(150 \times 150 \mathrm{DPI})$ 

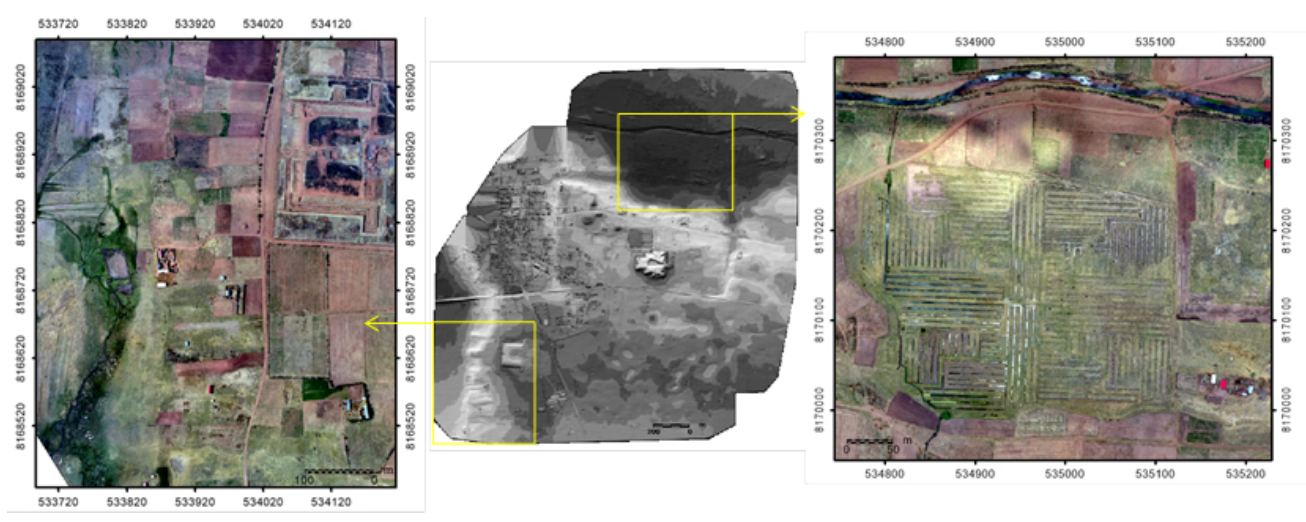

Figure 6. Left: Flood plains surrounding the Tiwanaku archaeological complex, obtained by UAV, November 2016. Right: detail of raised fields system, in northern Akapana territory

$140 \times 53 \mathrm{~mm}(150 \times 150 \mathrm{DPI})$ 
Figure 7. Detail of MDT: The archaeological site location, the neighbourhood and the surrounding flooded areas. (a): positive structures near of Akapana raised platform; (b): negative structures, channels and (c): positive structures near the Puma Punku raised platform

\author{
$170 \times 150 \mathrm{~mm}(150 \times 150 \mathrm{DPI})$
}




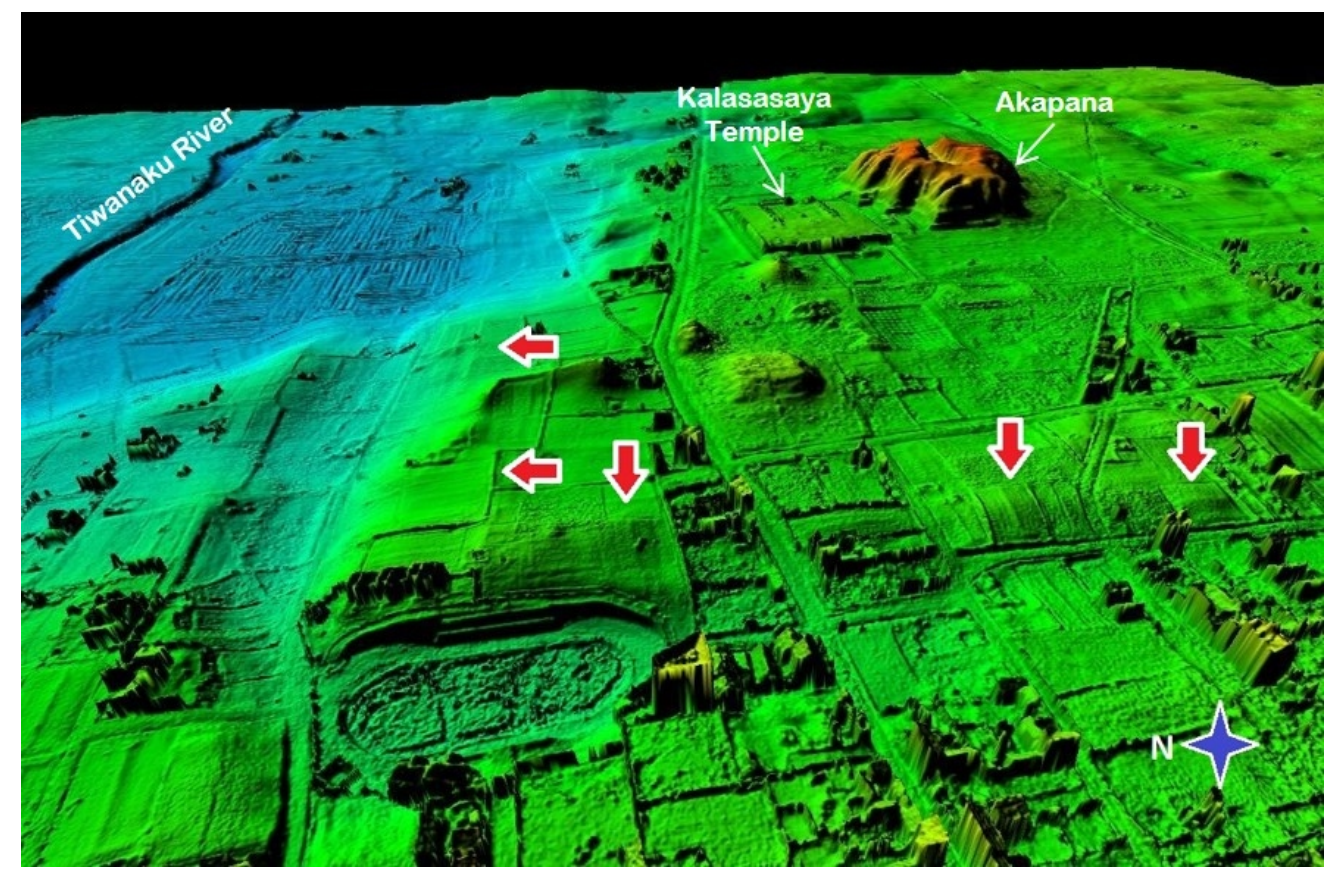

Figure 8. 3D rendering of NW corner of Tiwanaku's moat, by $16 \mathrm{~cm}$ resolution DTM. Marked with red arrows, position of remains of raised platforms attached to inner border of the moat

\section{$150 \times 98 \mathrm{~mm}(150 \times 150 \mathrm{DPI})$}




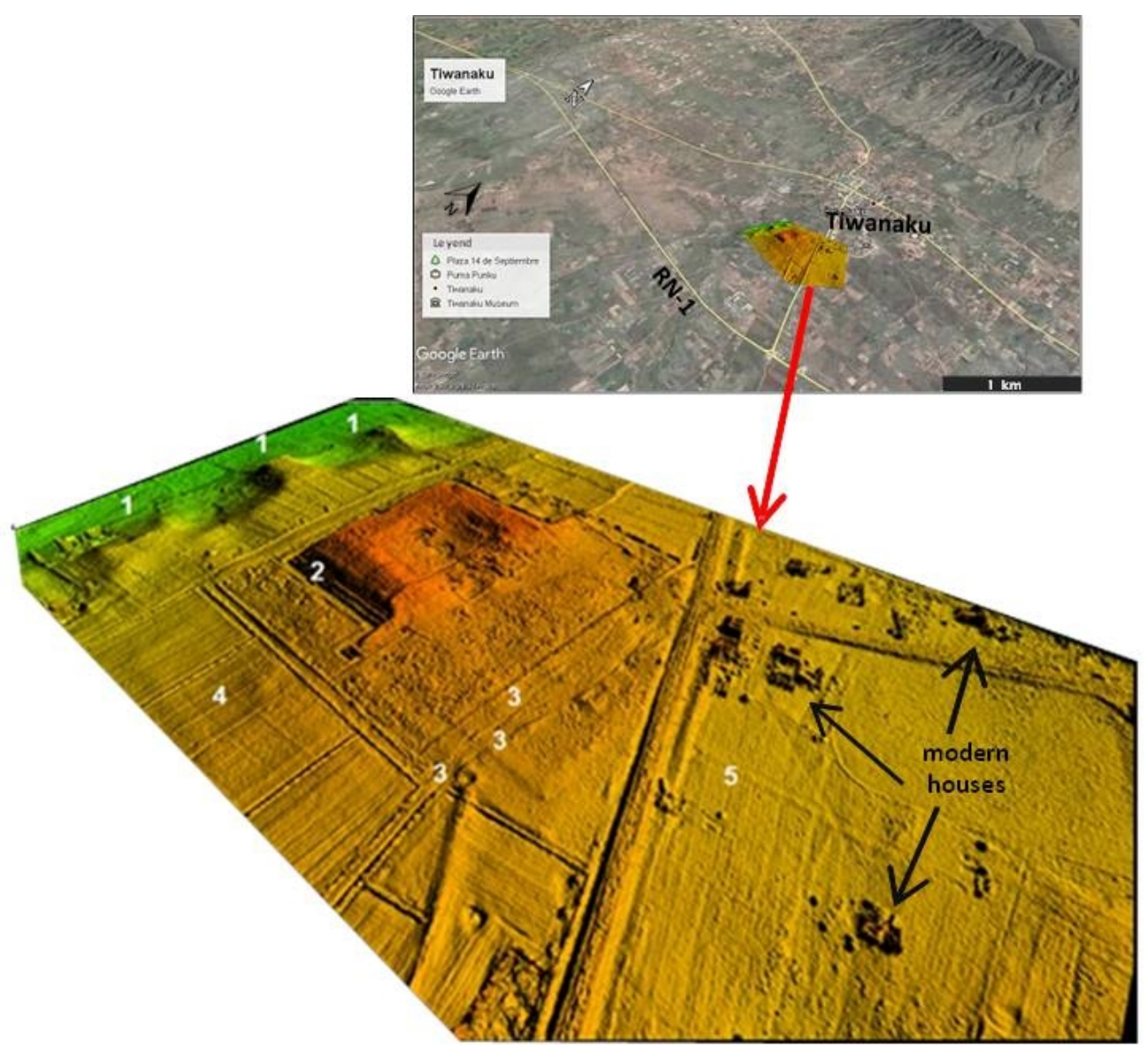

Figure 9. Location in Google Earth (up) and 3D Model (down): Puma Punku complex area view, obtained by DTM. Several structures can be observed linked to previously identified raised platform: 1 . Western complex buildings; 2. Puma Punku raised platform; 3. Eastern Platforms; 4. Southern buildings; 5. Eastern plaza

\section{$122 \times 109 \mathrm{~mm}(150 \times 150 \mathrm{DPI})$}




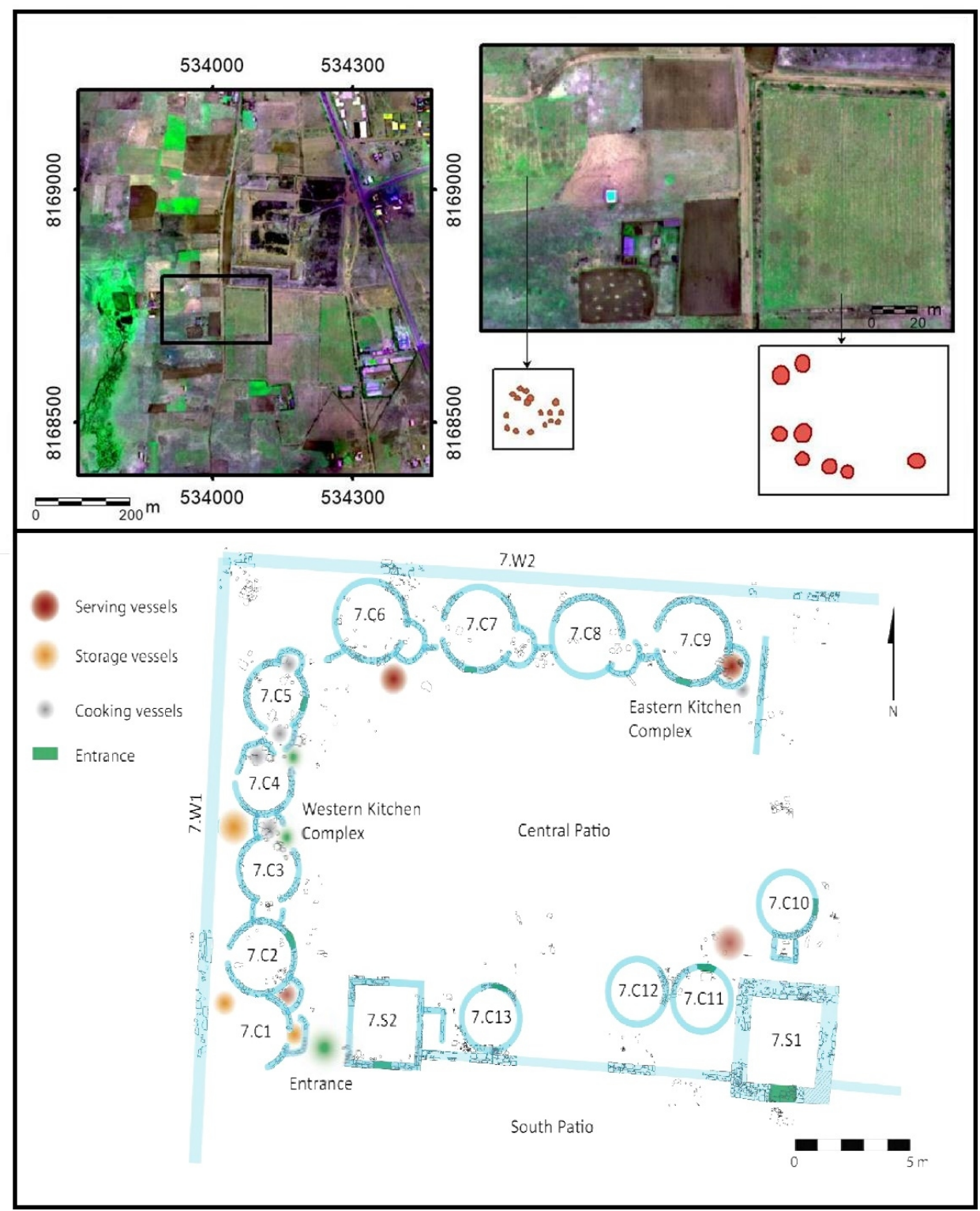

Figure 10. Multispectral imaging of southern Puma Punku area, with circular crop marks, compared with Khonkho Wankane site's domestic information (Marsh, 2016)

$$
199 \times 245 \mathrm{~mm}(150 \times 150 \text { DPI })
$$

